Ars Disputandi

Volume 3 (2003)

ISSN: $1566-5399$

Susanne Hennecke

UTRECHT UNIVERSITY, THE

NETHERLANDS

\title{
The Metaphysics of Love: Gender and Transcendence in Levinas
}

\author{
By Stella Sandford
}

London: Continuum, 2000; 179 pp.; hb. \$ 82.50, pb. \$ 29.95; ISBN: o-485-11566-2.

With The Metaphysics of Love: Gender and Transcendence in Levinas, Stella Sandford not only presents an excellent and lucid introduction to keythemes of the philosophy of Levinas, but also interesting criticisms of accepted feminist readings of Levinas. In five chapters, the author introduces and unfolds the thesis of her book: an immanent critique of the role of gender and transcendence in the writings of Levinas. Besides these five chapters, the reader finds a short but nevertheless very interesting Coda where Sandford discusses the recent feminist reception and critique of the connection between metaphysics and feminism in the work of Levinas, found in the works of the French philosopher Luce Irigaray and authors like Bracha Lichtenberg-Ettinger and Jacques Derrida. Here her refreshing conclusion is the rejection of the (politically correct) feminist claim upon the work of Levinas as representing a feminist point of view.

The main thesis defended in Sandford's book is that the philosophical project of Levinas is by no means exhausted by references to ethics and/or notions like the other and the face of the other. While the ethical project of Levinas can be seen as an attempt to speak about relevant themes as eros, sexual difference, the feminine and maternity, Sandford argues that this ethical project is to be seen as a mere means towards the development of a theory of metaphysics.

Therefore, the first theme of Sandford's book is the relation between ethics and metaphysics: Levinas' work can be seen as an attempt to rediscover and to recuperate Platonism, especially regarding the idea of transcendence. But Levinas is doing this in a very specific way, namely in conversation with philosophical contemporaries like Husserl and Heidegger-who, for Levinas, represent a betrayal of transcendence. Hence, notions like eros, sexual difference, the other and the face are only seemingly a resource for thinking through social-emancipatory power struggles-for example feminist or postcolonial power struggle. In fact, these ethical terms are to be understood in their philosophical/transcendental significance and are not to be reduced to their ethical functions and implications.

The second important theme is the questioning of the notion of 'the feminine' in the work of Levinas. Sandford shows that the notion of the feminine too is useless for describing the concrete feminist struggle. She points this out by reexamining the role of the feminine (and the eros) in the context of (paternal)

(C) October 22, 2003, Ars Disputandi. If you would like to cite this article, please do so as follows:

Susanne Hennecke, 'Review of The Metaphysics of Love: Gender and Transcendence in Levinas,' Ars Disputandi |http: //www. ArsDisputandi.org| 3 (2003). 
fecundity-a term by which Levinas expresses transcendence or the possibility that transcendence appears in the order of the world.

I can only recommend this lucidly written, original, and provocative book, even though it will be disappointing for those seeking in Levinas a direct ally in their liberatory struggles. I want to finish with a critical suggestion from a theological perspective about transcendence. From a theo-logical point of view - I would say - one can never separate ethics from transcendence (i.e. God speaking). From a theological point of view, ethics follows from transcendence rather than the other way round. A theological notion of transcendence always implies an intrinsic engagement with innerworldly struggle. The transcendent 'enters' (Latin: transiere) the innerworldly sphere, initiating its transformation. 